\title{
PENDEKATAN METODE POHON KEPUTUSAN \\ MENGGUNAKAN ALGORITMA ITERATIVE DICHOTOMIZER (ID3) UNTUK PENGUKURAN KINERJA PEGAWAI NEGERI SIPIL
}

\author{
Yoseph Pius Kurniawan Kelen ${ }^{1)}$,Yohanis Ndapa Deda ${ }^{2)}$ \\ 1) e-mail : yosepkelen@gmail.com, ${ }^{2)}$ e-mail: yndapadeda@ymail.com
}

\begin{abstract}
Decision tree method is a classification method that has been widely used for the solution of problems of classification. Decision tree classification provides a rapid and effective method. The approach has been proven decision tree method can be applied in various fields of life. Capability classification is indicated by the decision tree method is what encourages authors to use decision tree methods approach to measure the performance of civil servants.

To build a decision tree induction algorithms used. In this study, the ID3 algorithm method is used to construct a decision tree. Starting with the data collecting training samples and then measuring the entropy and information gain. Information Gain value will be used as the root of a decision tree. And translates it into a decision tree classification rules.

The results show that the decision tree method is used to produce classification rules into groups employee performance Good and Bad. The resulting rules are used to measure the performance of employees and classifying employees into two groups. The result to assist management in making more objective assessment process.
\end{abstract}

Keywords: ID3 Algorithm, Decision Tree, Employee Performance. 


\section{PENDAHULUAN}

Kinerja pegawai adalah salah satu unsur yang sangat menentukan kualitas suatu organisasi baik pemerintah maupun swasta. Bagi sebuah perusahan, entah itu perusahan produksi maupun jasa, karyawan menjadi ujung tombak dari perusahaan (Wibisono, 2011). Pada instansi pemerintahan, pegawai merupakan pelayan masyarakat yang menjamin nama baik dari sebuah instansi dan unit kerja (Safroni, 2012). Dengan fungsi yang sangat penting inilah maka kinerja pegawai perlu dikelola secara baik. Kinerja pegawai perlu diukur untuk menentukan apakah profesionalisme pegawai telah tercapai secara maksimal. Pengukuran kinerja pegawai telah banyak dilakukan. Pengukuran kinerja manusia (human performance) dapat menaikan tingkat produktifitas dari sebuah perusahaan selain dari kinerja sistem keuangan (McLean, 2009). Pengukuran kinerja dapat merangsang inisiatif karyawan untuk meningkatkan operasional kinerja, terutama ketika karyawan sendiri berpartisipasi dalam pengembangan ukuran kinerja departemen mereka sendiri (Groen dkk, 2012). Pengukuran kinerja secara rinci masing-masing pegawai perlu dilakukan untuk mencapai kinerja yang unggul. Keunggulan operasional dicapai melalui mekanisme yang didasarkan pada kepercayaan dan tanggung jawab pegawai (Platts dan Sobotka , 2010). Selain pengukuran yang dilakukan oleh pihak manajemen, evaluasi kinerja juga dapat dilakukan berdasarkan prespektif pelangan khususnya bagi perusahaan pengelola produk jasa (Noone, 2008). Begitu pentingnya pengukuran kinerja maka metode optimalisasi pengukuran kinerja terus dikembangkan, contohnya seperti konsep analisis maximal dan typical kinerja yang dilakukan dari waktu ke waktu (Diana dan Donald, 2008). Sistem pengukuran kinerja PNS yang selama ini dilakukan adalah menggunakan teknik penilaian skala dan metode kejadian kritis. Sistem pengukuran ini merupakan sistem penilaian yang berorientasi pada masa lalu, sehingga apabila tidak dilakukan sebagaimana mestinya hal ini bisa menimbulkan adanya bias penilaian berupa bias kesalahan yang terlalu lunak, kecenderungan nilai rata-rata dan penilaian berdasarkan kesan terakhir. Dimana kecenderungan proses penilaian dengan sistem rata-rata dan berdasarkan perilaku yang baru saja dilihat. Penilaian dengan sistem yang melibatkan satu orang penilai yaitu pejabat penilai menyebabkan sistem ini memiliki tingkat subjektifitas yang sangat tinggi. Sehingga pengukuran kinerja PNS yang lebih objektif merupakan sebuah kebutuhan yang harus dipenuhi dalam rangka perbaikan kualitas dan performa PNS itu sendiri.

Metode decision tree atau pohon keputusan merupakan metode klasifikasi yang telah banyak digunakan untuk penyelesaian masalah-masalah klasifikasi. Klasifikasi pohon keputusan menyediakan metode yang cepat dan efektif untuk mengelompokkan dataset (Aitkenhead, 2008). Bahkan pengembangan terhadap metode pohon keputusan telah dilakukan untuk menghasilkan pendekatan yang mampu mengklasifikasi data-data sensitif (Barak dan Gelbard, 2011). Pendekatan metode pohon keputusan telah terbukti dapat diaplikasikan dalam berbagai bidang kehidupan. Penggunaan algoritma induksi pohon keputusan pada data Rumah Sakit Surveilans untuk mengklasifikasikan pasien berdasarkan kondisi kritis yang dialami (Rahman dan Hasan, 2011). Pembangunan Intrusion Detection System (IDS) berbasis pohon keputusan untuk mendeteksi anomali dalam jaringan (Sindhu dkk, 2012). Metode pohon keputusan juga dapat dikombinasikan dengan metode lain untuk hasil penyelesaian masalah yang lebih maksimal. Pendekatan sistematis untuk merancang desain konsep produk konvergen atau digital berdasarkan informasi komunitas online menggunakan teknik data mining ARM dan pohon keputusan (Lee dkk, 2012). pohon keputusan dan algoritma genetika untuk pemantauan kondisi AC pesawat (Gerdes, 2013). Optimasi metode koloni semut berbasis Fuzzy biner pohon keputusan untuk sistem verifikasi pola tangan (Kumar dkk, 2013).

Untuk membangun sebuah pohon keputusan, digunakan algoritma induksi. Algoritma induksi yang dikenal antara lain : ID3, CART, C4.5, SLIQ, PUBLIK, SPRINT, 
RAINFOREST, BOAT, MMDT, dan TASC (Chen dan Hung, 2009) . Masing-masing algoritma memiliki kemampuan yang berbeda-beda sesuai dengan studi kasus dan pemasalahan. Algoritma ID3 memiliki kemampuan klasifikasi yang paling sederhana. Algoritma ID3 adalah konsep algoritma pembelajaran yang bermanfaat karena dapat membangun pohon keputusan secara baik dan efisien (Balamurugan dan Rajaram, 2009). Untuk kasus-kasus pembelajaran yang sederhana, algoritma ini sering merupakan pilihan yang ideal untuk membangun aturan klasifikasi. Kemampuan klasifikasi yang ditunjukkan oleh metode pohon keputusan seperti yang dijelaskan diatas dan kesederhaan proses yang ditawarkan oleh algoritma ID3, maka pada penelitian ini akan dilakukan suatu sistem analisis klasifikasi terhadap kinerja PNS untuk menentukan tingkat profesionalisme pegawai. Pendekatan yang digunakan adalah metode pohon keputusan dengan algoritma ID3 (Iterative Dichotomiser 3).

Penelitian ini bertujuan untuk menghasilkan sebuah sistem informasi analisis klasifikasi kinerja pegawai negeri sipil menggunakan metode pohon keputusan. Manfaat penelitian ini adalah kontribusi keilmuan penggunaan metode klasifikasi pohon keputusan untuk mengukur kinerja pegawai negeri sipil. Namun, dengan melihat berbagai jenis status kepegawaian yang terbagi atas dua kelompok yaitu struktural dan fungsional maka penelitian ini memiliki batasan hanya pada PNS di tingkat struktural. Hasil penelitian yang diperoleh diharapkan dapat memberikan manfaat bagi lembaga yang berwenang dalam melakukan penilaian kinerja pegawai negeri sipil yang lebih objektif.

\section{KAJIAN PUSTAKA}

\section{a) Pohon Keputusan}

Pohon keputusan adalah sebuah struktur data yang terdiri dari simpul (node) dan rusuk (edge) simpul pada sebuah pohon dibedakan menjadi tiga, yaitu simpul akar (root node), simpul percabangan (branch node) dan simpul daun atau leaf node (Hermawati, 2013). Secara ringkas, langkah kerja algoritma ID3 dapat digambarkan sebagai berikut (Defiyanti dan Pardede, 2009) :

1. Input sampel training, label training, dan atribut.

2. Hitung Entropy dan Information Gain dari setiap atribut dengan rumus

Entropy $(\mathrm{S})=-\mathrm{P}_{+} \log _{2} \mathrm{P}_{+}-\mathrm{P}_{-} \log _{2} \mathrm{P}_{-}$

Dimana:

$\mathrm{S}=$ ruang (data) sample yang digunakan untuk training.

$\mathrm{P}+=$ jumlah yang bersolusi positif (mendukung) pada data sample untuk kriteria tertentu.

P- = jumlah yang bersolusi negatif (tidak mendukung) pada data sample untuk kriteria tertentu.

$$
\operatorname{Gain}(S, A)=\operatorname{Entropy}(S)-\sum_{\text {venilai }(A)} \frac{\left\|S_{v}\right\|}{\| S \mid} \operatorname{Entropy}\left(S_{v}\right) \quad\left(\begin{array}{ll}
2.2 & 2.2
\end{array}\right)
$$

Dimana :

$\mathrm{S} \quad=$ ruang (data) sample yang digunakan untuk training.

A $\quad$ atribut.

$\mathrm{V}=$ Suatu nilai yang mungkin untuk atribut $\mathrm{A}$.

Nilai(A) = Himpunan yang mungkin untuk atribut $\mathrm{A}$.

$|\mathrm{Sv}|=$ Jumlah sample untuk nilai $\mathrm{V}$.

$|\mathrm{S}| \quad=$ jumlah seluruh sample data.

Entropy $(\mathrm{Sv})=$ entropy untuk sample-sample yang memiliki nilai $\mathrm{V}$. 
3. Bentuk simpul yang berisi atribut tersebut.

4. Ulangi proses perhitungan information gain seperti pada langkah ke-2 yang akan terus dilaksanakan sampai semua data telah termasuk dalam kelas yang sama. Atribut yang telah dipilih tidak diikutkan lagi dalam perhitungan nilai information gain.

Model pohon keputusan ditunjukan pada Gambar 2.1 (Aitkenhead, 2008).

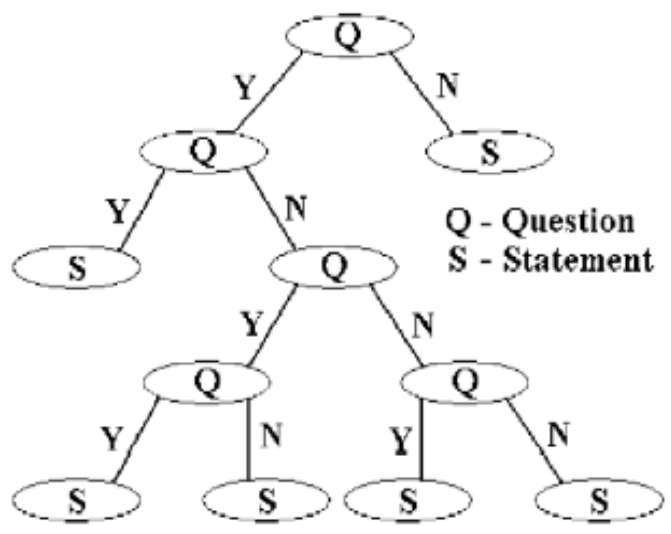

Gambar 2.1 Gambaran sebuah pohon keputusan

Penelitian ini menggunakan algoritma ID3 (Iterative Dechotomizer 3). Algoritma ID3 adalah algoritma pembelajaran pohon keputusan yang sederhana dikembangkan oleh J. Ross Quinlan pada tahun 1993. Algoritma ID3 melakukan prosedur pencarian secara menyeluruh pada semua kemungkinan pohon keputusan. Alasan terbesar menggunakan algoritma ID3 adalah kesederhanaan yang ditawarkan metode ini dalam mengklasifikasikan data. Walau dengan proses yang sederhana, namun dapat menghasilkan hasil klasifikasi yang akurat.

Langkah kerja algoritma ID3 diatas dapat digambarkan lewat flowchart pada Gambar

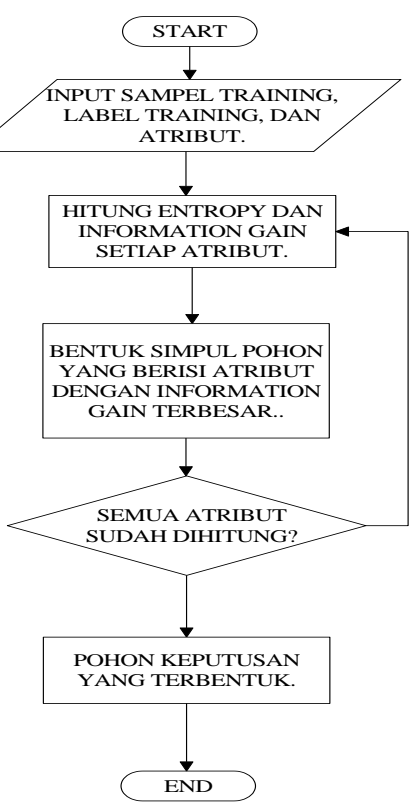

Gambar 2.2 Flowchart Cara Kerja Algortima ID3. 


\section{b) Kinerja PNS}

Kinerja PNS ditentukan berdasarkan sistem prestasi dan sistem karir yang dititikberatkan pada sistem prestasi kerja. Sistem penilaian kinerja PNS disebut dengan istilah pembinaan dalam manajemen PNS. Manajemen PNS diarahkan untuk menjamin penyelenggaraan tugas pemerintahan dan pembangunan secara berdayaguna dan berhasilguna.Untuk mewujudkan penyelengaraan tugas pemerintahan dan pembangunan inilah, diperlukan Pegawai Negeri Sipil yang profesional, bertanggung jawab, jujur, dan adil.

Prosedur penilaian kinerja PNS dilakukan oleh masing-masing pimpinan unit kerja. Namun, yang bertanggungjawab mengelolah proses penilaian kinerja adalah Badan Kepegawaian Negara (BKN) yang memliki perwakilan di masing-masing daerah yaitu Badan Kepegawaian Daerah (BKD). BKD inilah yang akan mengatur semua proses pembinaan dari saat formasi, pengangkatan, penempatan, mutasi, disiplin hingga pemberhentian pegawai.

Sesuai dengan ketentuan Peraturan Pemerintah Nomor 10 Tahun 1979 tentang Penilaian Pelaksanaan Pekerjaan Pegawai Negeri Sipil, diuraikan bahwa yang menjadi unsur-unsur penilaian kinerja PNS adalah

- Kesetiaan, nilai kepatuhan terhadap Pancasila dan Negara Kesatuan Republik Indonesia serta Pemerintah Republik Indonesia.

- Prestasi Kerja, kemampuan untuk menguasai segala bentuk tugas dan pekerjaan sebagai PNS.

- Tanggung Jawab, kemampuan menyelesaikan tugas dengan sebaik-baiknya dan tepat waktu.

- Ketaatan, kepatuhan terhadap Undang-Undang dan Peraturan Pemerintah serta memberikan pelayanan yang maksimal kepada masyarakat.

- Kejujuran, melaksanakan tugas dengan ikhlas dan tidak menyalagunakan wewenang dan jabatan.

- Kerjasama, memiliki kemampuan bekerja dalam tim, menjaga hubungan dengan sesama pegawai.

- Prakarsa, memiliki kemampuan untuk berinisiatif dan kreatif dalam melaksanakan tugas.

- Kepemimpinan, kemampuan untuk memimpin anggota dalam suatu unit kerja. Unsur ini berlaku bagi mereka yang memiliki jabatan.

Semua unsur-unsur ini dituangkan dalam Daftar Penilaian Pelaksanaan Pekerjaan yang disingkat dengan DP3.

\section{METODE PENELITIAN}

Tahapan dari prosedur penelitian dimulai dengan menentukan atribut atau variabel yang menjadi objek penelitian dengan merujuk pada Undang-Undang Republik Indonesia Nomor 43 Tahun 1999 Tentang Perubahan atas Undang-Undang Nomor 8 Tahun 1974 Tentang Pokok-Pokok Kepegawaian. Kemudian menghitung nilai Entropy dan Informasi Gain menggunakan Algoritma ID3. Ditunjukan dengan membangun pohon keputusan berdasarkan nilai Gain terbesar yang telah diperoleh. Tahapan terakhir adalah menghitung tingkat akurasi dari data yang diolah. Adapun prosedur dari penelitian ini ditunjukkan oleh Gambar 3.1 berikut : 


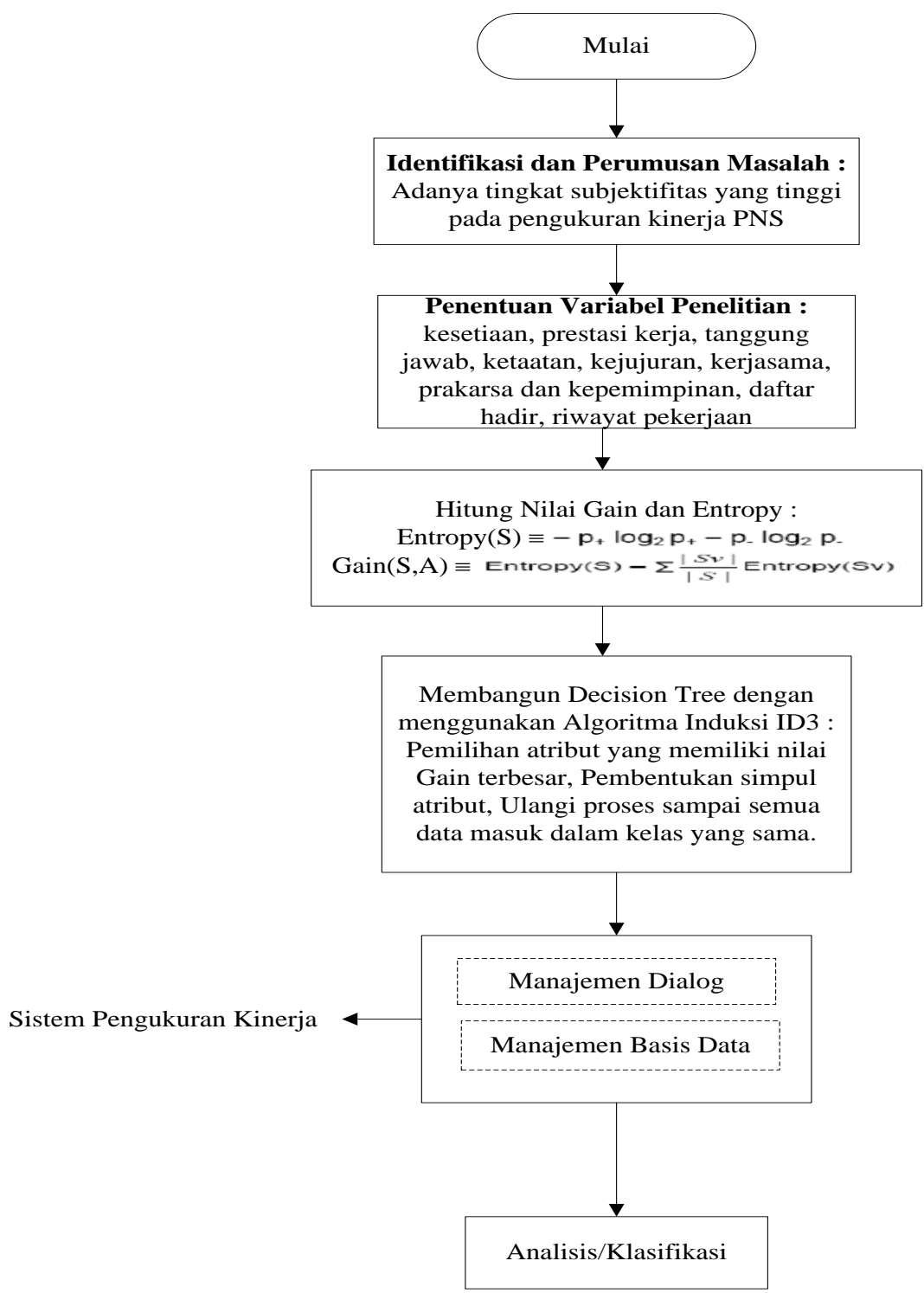

Gambar 3.1 Prosedur Penelitian

Deskripsi Variabel

Setiap variabel memiliki nilai atau kategori sebagai berikut :

Variabel Kehadiran dikelompokkan dalam 3 kategori yaitu: Ringan, Sedang, dan Berat.Variabel Kesetiaan dikelompokkan dalam 3 kategori yaitu: Amat Baik, Baik, dan Cukup.Variabel Prestasi Kerja dikelompokkan dalam 3 kategori yaitu: Amat Baik, Baik, dan Cukup.Variabel Tanggung Jawab dikelompokkan dalam 3 kategori yaitu: Amat Baik, Baik, dan Cukup.Variabel Ketaatan dikelompokkan dalam 3 kategori yaitu: Amat Baik, Baik, dan Cukup.Variabel Kejujuran dikelompokkan dalam 3 kategori yaitu: Amat Baik, Baik, dan Cukup.Variabel Kerjasama dikelompokkan dalam 3 kategori yaitu: Amat Baik, Baik, dan Cukup.

Variabel Prakarsa dikelompokkan dalam 3 kategori yaitu: Amat Baik, Baik, dan Cukup.Variabel Kepemimpinan dikelompokkan dalam 3 kategori yaitu: Amat Baik, Baik, 
dan Cukup. Terdapat 127 sampel pegawai yang diinisialisasikan dalam P1 sampai P127 yang diambil data penilaiannya. Dengan 3 kategori yang dikelompokan dari masing-masing variabel yaitu: amat baik (91-100), baik (76-90), dan cukup (61-75). Dan 3 kategori lagi yaitu: ringan (5-15), sedang (16-30), dan berat $(\geq 31)$ untuk kehadiran. Maka untuk data yang lengkap seharusnya terdapat 19683 total kombinasi sampel data, akan tetapi dalam tabel diatas hanya terdapat 127 kombinasi artinya masih ada 19556 kombinasi yang belum diketahui. Dengan penggunaan sistem klasifikasi pohon keputusan menggunakan algoritma ID3, aturan atau data yang belum diketahui bisa kita temukan untuk menentukan kualitas kinerja pegawai.

\section{HASIL PENELITIAN}

Analisis Information Gain :

Jumlah kelas ada 2, yaitu: Bagus dan Buruk $(\mathrm{c}=2)$

Jumlah sampel kelas (Bagus) adalah 56, dan Jumlah sampel kelas (Buruk) adalah 71, jadi P1 adalah 56 dan P2 adalah 71.

Entropy atau kumpulan sampel data $S$ adalah:

Entropy $(S)=-(56 / 127) \log 2(56 / 127)-(71 / 127) \log 2(71 / 127)=0,9899$

Atribut Kinerja = "Bagus" merupakan sampel $(+)$, dan atribut Kinerja $=$ "Buruk" merupakan sampel (-), dari sampel data pada tabel, didapat:

Values (nil.Kehadiran) $=$ Ringan, Sedang, Berat.

$\mathrm{S}=[56+, 71-],|\mathrm{S}|=127$

$\mathrm{S}_{\text {Ringan }}=[28+, 17-], \mid$ Ringan $\mid=45$

$\mathrm{S}_{\text {Sedang }}=[28+, 17-], \mid$ Sedang $\mid=45$

$\mathrm{S}_{\text {Berat }}=[0+, 37-], \mid$ Berat $\mid=37$

Hitung entropy $S_{\text {Ringan, }} S_{\text {Sedang, }}, S_{\text {Berat }}$ sebagai berikut:

Entropy $(S)=0,9899$

Entropy $\left(\mathrm{S}_{\text {Ringan }}\right)=(-28 / 45) \log _{2}(28 / 45)-(17 / 45) \log _{2}(17 / 45)=0,9565$

Entropy $\left(S_{\text {Sedang }}\right)=(-28 / 45) \log _{2}(28 / 45)-(17 / 45) \log _{2}(17 / 45)=0,9565$

Entropy $\left(S_{\text {Berat }}\right)=(-0 / 37) \log _{2}(0 / 37)-(37 / 37) \log _{2}(37 / 37)=0$

Information Gain ( $\mathrm{S}$, Nil.Kehadiran)

$=$ Entropy $(\mathrm{S})-\sum_{v e(\text { Ringan,Sedang,Berat })} \frac{\| s v \mid}{\| s \mid}$ Entropy $(S v)$

$=0,9899-(((45 / 127) * 0,9565)+((45 / 127) * 0,9565)+((37 / 127) * 0))$

$=0,9899-0,6778$

$=\mathbf{0}, \mathbf{3 1 2 1}$

Values $($ nil.Kesetiaan $)=$ Amat Baik, Baik, Cukup

$\mathrm{S}=[56+, 71-],|\mathrm{S}|=127$

$\mathrm{S}_{\text {Amat Baik }}=[28+, 49-], \mid$ Amat Baik $\mid=77$

$\mathrm{S}_{\text {Baik }}=[28+, 19-], \mid$ Baik $\mid=47$

$\mathrm{S}_{\text {Cukup }}=[0+, 3-], \mid$ Cukup $\mid=3$

Hitung entropy $S_{\text {AmatBaik, }}, S_{\text {Baik, }}, S_{\text {Cukup }}$ adalah:

Entropy $(S)=0,9899$

Entropy $\left(\mathrm{S}_{\text {Amat Baik }}\right)=(-28 / 77) \log _{2}(28 / 77)-(49 / 77) \log _{2}(49 / 77)=0,9457$

Entropy $\left(S_{\text {Baik }}\right)=(-28 / 47) \log _{2}(28 / 47)-(19 / 47) \log _{2}(19 / 47)=0,9734$

Entropy $\left(\mathrm{S}_{\text {Cukup }}\right)=(-0 / 3) \log _{2}(0 / 3)-(3 / 3) \log _{2}(3 / 3)=0$

Information Gain (S, Nil.Kesetian)

$=$ Entropy $(\mathrm{S})-\sum_{v e(\text { AmatBaik,Baik,Cukup) }} \frac{\| s v \mid}{|s|}$ Entropy $(S v)$

$=0,9899-(((77 / 127) * 0,9457)+((47 / 127) * 0,9734)+((3 / 127) * 0))$

$=0,9899-0,9336$ 


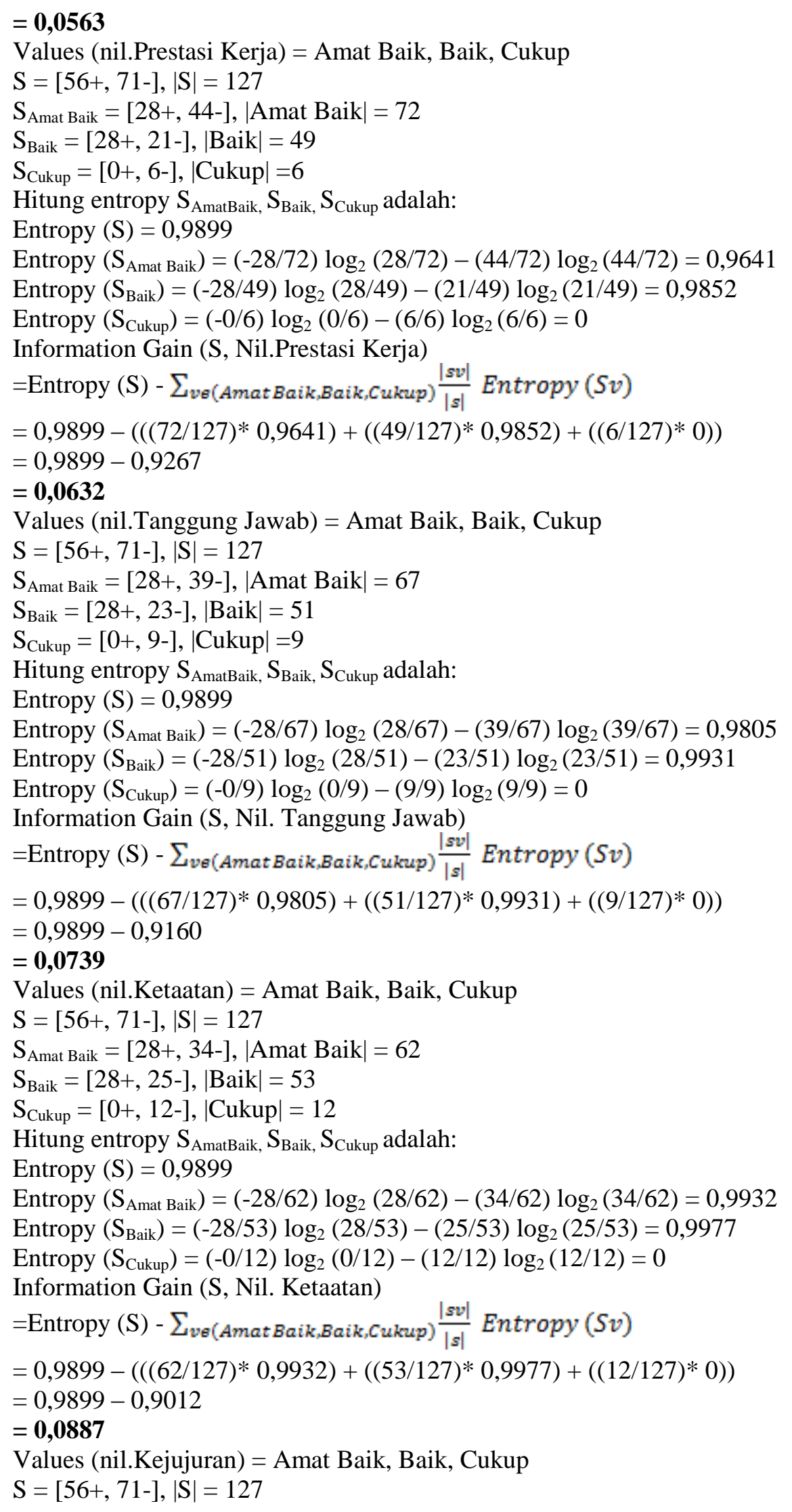


$\mathrm{S}_{\text {Amat Baik }}=[28+, 29-], \mid$ Amat Baik $\mid=57$

$\mathrm{S}_{\text {Baik }}=[28+, 27-], \mid$ Baik $\mid=55$

$\mathrm{S}_{\text {Cukup }}=[0+, 15-], \mid$ Cukup $\mid=15$

Hitung entropy $S_{\text {AmatBaik, }} S_{\text {Baik, }} S_{\text {Cukup }}$ adalah:

Entropy $(S)=0,9899$

Entropy $\left(\mathrm{S}_{\text {Amat Baik }}\right)=(-28 / 57) \log _{2}(28 / 57)-(29 / 57) \log _{2}(29 / 57)=0,9998$

Entropy $\left(\mathrm{S}_{\text {Baik }}\right)=(-28 / 55) \log _{2}(28 / 55)-(27 / 55) \log _{2}(27 / 55)=0,9998$

Entropy $\left(\mathrm{S}_{\text {Cukup }}\right)=(-0 / 15) \log _{2}(0 / 15)-(15 / 15) \log _{2}(15 / 15)=0$

Information Gain ( $\mathrm{S}$, Nil. Kejujuran)

$=$ Entropy $(\mathrm{S})-\sum_{v e(\text { AmatBaik,Baik,Cukup) }} \frac{|s v| \mid}{\| s \mid}$ Entropy (Sv)

$=0,9899-(((57 / 127) * 0,9998)+((55 / 127) * 0,9998)+((15 / 127) * 0))$

$=0,9899-0,8817$

$\mathbf{= 0 , 1 0 8 2}$

Values $($ nil.Kerjasama) $=$ Amat Baik, Baik, Cukup

$\mathrm{S}=[56+, 71-],|\mathrm{S}|=127$

$\mathrm{S}_{\text {Amat Baik }}=[28+, 24-], \mid$ Amat Baik $\mid=52$

$\mathrm{S}_{\text {Baik }}=[28+, 29-], \mid$ Baik $\mid=57$

$\mathrm{S}_{\text {Cukup }}=[0+, 18-], \mid$ Cukup $\mid=18$

Hitung entropy $\mathrm{S}_{\text {AmatBaik, }} \mathrm{S}_{\text {Baik, }} \mathrm{S}_{\text {Cukup }}$ adalah:

Entropy $(\mathrm{S})=0,9899$

Entropy $\left(\mathrm{S}_{\text {Amat Baik }}\right)=(-28 / 52) \log _{2}(28 / 52)-(24 / 52) \log _{2}(24 / 52)=0,9957$

Entropy $\left(\mathrm{S}_{\text {Baik }}\right)=(-28 / 57) \log _{2}(28 / 57)-(29 / 57) \log _{2}(29 / 57)=0,9998$

Entropy $\left(\mathrm{S}_{\text {Cukup }}\right)=(-0 / 18) \log _{2}(0 / 18)-(18 / 18) \log _{2}(18 / 18)=0$

Information Gain (S, Nil. Kerjasama)

$=$ Entropy $(\mathrm{S})-\sum_{v e(\text { AmatBaik,Baik,Cukup) }} \frac{\| s v||}{\|s\|}$ Entropy $(S v)$

$=0,9899-(((52 / 127) * 0,9957)+((57 / 127) * 0,9998)+((18 / 127) * 0))$

$=0,9899-0,8564$

$\mathbf{= 0 , 1 3 3 5}$

Values (nil.Prakarsa) $=$ Amat Baik, Baik, Cukup

$\mathrm{S}=[56+, 71-],|\mathrm{S}|=127$

$\mathrm{S}_{\text {Amat Baik }}=[28+, 19-], \mid$ Baik $\mid=47$

$\mathrm{S}_{\text {Baik }}=[28+, 31-], \mid$ Baik $\mid=59$

$\mathrm{S}_{\text {Cukup }}=[0+, 21-], \mid$ Cukup $\mid=21$

Hitung entropy $S_{\text {AmatBaik, }} S_{\text {Baik }}, S_{\text {Cukup }}$ adalah:

Entropy $(S)=0,9899$

Entropy $\left(\mathrm{S}_{\text {Amat Baik }}\right)=(-28 / 47) \log _{2}(28 / 47)-(19 / 47) \log _{2}(19 / 47)=0,9734$

Entropy $\left(\mathrm{S}_{\text {Baik }}\right)=(-28 / 59) \log _{2}(28 / 59)-(31 / 59) \log _{2}(31 / 59)=0,9981$

Entropy $\left(\mathrm{S}_{\text {Cukup }}\right)=(-0 / 21) \log _{2}(0 / 21)-(21 / 21) \log _{2}(21 / 21)=0$

Information Gain (S, Nil. Prakarsa)

$=$ Entropy $(\mathrm{S})-\sum_{v e(\text { AmatBaik,Baik,Cukup) })} \frac{\| s v \mid}{|s|}$ Entropy $(S v)$

$=0,9899-(((47 / 127) * 0,9734)+((59 / 127) * 0,9981)+((21 / 127) * 0))$

$=0,9899-0,8239$

$=\mathbf{0 , 1 6 6 0}$

Values (nil.Kepemimpinan $)=$ Amat Baik, Baik, Cukup

$\mathrm{S}=[56+, 71-],|\mathrm{S}|=127$

$\mathrm{S}_{\text {Amat Baik }}=[28+, 14-], \mid$ Amat Baik $\mid=42$

$S_{\text {Baik }}=[28+, 14-], \mid$ Baik $\mid=42$ 
$\mathrm{S}_{\text {Cukup }}=[0+, 43-], \mid$ Cukup $\mid=43$

Hitung entropy $S_{\text {AmatBaik, }} S_{\text {Baik, }}, S_{\text {Cukup }}$ adalah:

Entropy $(S)=0,9899$

Entropy $\left(\mathrm{S}_{\text {Amat Baik }}\right)=(-28 / 42) \log _{2}(28 / 42)-(14 / 42) \log _{2}(14 / 42)=0,9183$

Entropy $\left(\mathrm{S}_{\text {Baik }}\right)=(-28 / 42) \log _{2}(28 / 42)-(14 / 42) \log _{2}(14 / 42)=0,9183$

Entropy $\left(\mathrm{S}_{\text {Cukup }}\right)=(-0 / 43) \log _{2}(0 / 43)-(43 / 43) \log _{2}(43 / 43)=0$

Information Gain (S, Nil. Kepemimpinan)

$=$ Entropy $(\mathrm{S})-\sum_{v e(\text { AmatBaik,Baik,Cukup) }} \frac{|s v|}{|s|}$ Entropy (Sv)

$=0,9899-(((42 / 127) * 0,9183)+((42 / 127) * 0,9183)+((43 / 127) * 0))$

$=0,9899-0,6074$

$\mathbf{0} \mathbf{0 , 3 8 5 2}$

\section{Pembahasan}

Dari nilai Information Gain sebanyak sembilan atribut yaitu; Kehadiran, Kesetiaan, Prestasi Kerja, Tanggung Jawab, Ketaatan, Kejujuran, Kerjasama, Prakarsa, dan Kepemimpinan diakumulasi sebagai berikut:

$\mathrm{IG}$ (S, Nil. Kehadiran) $\quad=\mathbf{0 , 3 1 2 1}$

IG (S, Nil. Kesetiaan) $\quad=\mathbf{0 , 0 5 6 3}$

IG (S, Nil. Prestasi Kerja) $=\mathbf{0 , 0 6 3 2}$

IG (S, Nil. Tanggung Jawab) $\quad=\mathbf{0 , 0 7 3 9}$

IG (S, Nil. Ketaatan) $\quad=\mathbf{0 , 0 8 8 7}$

$\mathrm{IG}(\mathrm{S}, \mathrm{Nil}$. Kejujuran) $\quad=\mathbf{0 , 1 0 8 2}$

IG (S, Nil. Kerjasama) $\quad=\mathbf{0 , 1 3 3 5}$

IG (S, Nil. Prakarsa) $\quad=\mathbf{0 , 1 6 6 0}$

IG (S, Nil. Kepemimpinan) $\quad=\mathbf{0 , 3 8 5 2}$

Dari kesembilan nilai Information Gain tersebut, Gain (S, Nil.Kepemimpinan) adalah yang terbesar, sehingga atribut Kehadiran adalah best classifier dan harus diletakkan sebagai root.

\section{PENUTUP}

\section{a) Kesimpulan}

Berdasarkan hasil penelitian, dapat diambil beberapa kesimpulan sebagai berikut : Pohon keputusan adalah teknik klasifikasi yang membangun model klasifikasi dari suatu himpunan data masukan. Pohon keputusan menggunakan suatu algoritma pembelajaran untuk mendapatkan model klasifikasi. Sehingga data masukan menjadi hal yang penting pengaruhnya dalam pembentukan pohon keputusan dan aturan yang dihasilkan. Algoritma ID3 dapat menghasilkan pemodelan pohon keputusan dengan proses pemangkasan pohon menjadi lebih sederhana, sehingga cocok untuk data-data yang memiliki tingkat variasi yang komplit. Perhitungan yang dihasilkan dapat meningkatkan objektifitas dari proses penilaian pegawai dengan melibatkan beberapa subjek penilai sehingga menjadi kombinasi penilaian yang lebih objektif. Dengan ditambahkan kehadiran sebagai salah satu unsur dalam penilaian memberikan dampak yang positif dalam memaju tingkat disiplin pegawai dalam hal kehadiran di tempat kerja.

\section{b) Saran}

Penggunaan algoritma ID3 dapat dikombinasikan dengan metode yang lain khusus untuk pembobotan dapat menghasilkan hasil klasifikasi yang lebih tepat dan menghasilkan pohon keputusan yang lebih baik. Setiap atribut yang digunakan dalam penilaian perlu diuraikan dengan lebih rinci kategori-kategorinya agar memudahkan dalam proses penilaian. 
Aturan dari pohon keputusan yang dihasilkan adalah sistem pendukung keputusan. Fungsinya untuk membantu pihak manajemen dalam proses penilaian pegawai, sehingga sistem ini bisa dijadikan referensi dalam mengambil kebijakan penentuan kinerja aparatur negara.

\section{DAFTAR PUSTAKA}

Aitkenhead, M. J., 2008, A co-evolving decision tree classification method, Expert Systems with Applications 34, 18-25.

Barak, A., Gelbard, R., 2011, Classification by clustering decision tree-like classifier based on adjusted clusters Expert Systems with Applications 38, 8220-8228

Balamurugan, S.A, Ramasamy R., 2009, Effective solution for unhandled exception in decision tree induction algorithms, Expert Systems with Applications (36), 12113-12119.

Chen, Y., Hung, L.T., 2009, Using decision trees to summarize associative classification rules, Expert Systems with Applications 36, 2338-2351.

Diana, D.L., Donald, G.G., 2008, Maximal and typical measures of job performance: An analysis of performance variability over time, Human Resource Management Review 18, 133-145.

Defiyanti, S., Pardede, C.D.L., 2009, Perbandingan Kinerja Algoritma ID3 dan C4.5 Dalam Klasifikasi Spam-Mail, Skripsi, Universitas Gunadarma, Jakarta.

Gerdes, M., 2013, Decision trees and genetic algorithms for condition monitoring forecasting of aircraft air conditioning, Expert Systems with Applications 40, 5021-5026

Groen, B.A.C., Wouters J.F, Wilderom C.P.M, 2012, Why do employees take more initiatives to improve their performance after co-developing performance measures? A field study, Elsevier Management Accounting Research 23, 120-141.

Hermawati, F.A., 2013, Data Mining, Penerbit Andi Offset, Yogyakarta.

Kumar, A., Hanmandlu, M., Gupta, H.M., 2013, Ant colony optimization based fuzzy binary decision tree for bimodal hand knuckle verification system Expert Systems with Applications 40, 439-449.

Lee, C., Song, B., Park, Y., 2012, Design of convergent product concepts based on functionality: An association rule mining and decision tree approach Expert Systems with Applications 39, 9534 9542.

McLean, T., 2009, The measurement and management of human performance in seventeenth century English farming: The case of Henry Best, Elsevier Accounting Forum 33, 62-73.

Noone, B.M., 2008, Customer perceived control and the moderating effect of restaurant type on evaluations of restaurant employee performance, International Journal of Hospitality Management 27, 23-29

O’Brien, J.A., 2008, Pengantar Sistem Informasi, Prespektif Bisnis dan Manajerial Edisi 12, Penerbit Salemba Empat, Jakarta.

Platts, K.W., Sobotka M, 2010, When the uncountable counts: An alternative to monitoring employee performance, Business Horizons 53, 349-357.

Rahman, R.M., Hasan, F.R.Md., 2011, Using and comparing different decision tree classification techniques for mining ICDDR,B Hospital Surveillance data, Expert Systems with Applications $38,11421-11436$.

Sindhu, S.S.S., Geetha, S., Kannan, A., 2012, Decision tree based light weight intrusion detection using a wrapper approach, Expert Systems with Applications 39, 129-141.

Ture, M., Fusun, T., Imran, K., 2009, Using Kaplan-Meier analysis together with decision tree methods (C\&RT, CHAID, QUEST, C4.5 and ID3) in determining recurrence-free survival of breast cancer patients, Expert Systems with Applications 36, 2017-2026. 